\title{
Koulutus- ja tiedeyhteisön autonomia
}

\author{
Juha Manninen
}

Dosentti J.V. S n e $11 \mathrm{~m}$ a n ilmoitti loppuvuodesta 1837 aikomuksensa pitää Keisarillisen Aleksanterin yliopiston ylioppilaille sarjan luentoja "akateemisen vapauden todellisesta luonnosta ja olemuksesta". Hän arveli, että "yliopiston, sivistyslaitoksena, tulee ohjata nuorisoa lapsellisesta auktoriteettiuskosta itsenäiseen vakaumukseen" ja että yliopistollinen vapaus on tarpeen tällaisen kehityksen mahdollistajana.

Rehtori kielsi luennot. Snellman jätti valituskirjelmän ja konsistorin närkästys oli suuri. Syntyneen oikeuskäsittelyyn saakka johtaneen jupakan kuluessa Snellmania uhkailtiin eri tavoin. Vt. kansleri, kreivi Rehbinder totesi Pietarissa, että "kysymyksessä olevaa ainetta ei saa luennoissa opiskelevalle nuorisolle julkisesti eikä yksityisesti millään tavalla kosketella, vielä vähemmän käsitellä’. Myöhemmin Rehbinder vielä korosti, että "yliopiston asetukset ja kurinpitosäädökset ylioppilaita varten käsittävät kaikki tarpeelliset määräykset asiassa" sekä että "nämä määräykset eivät kaipaa mitään selityksiä, vaan ainoastaan ehdotonta tottelemista".

Hovioikeuden päätöksellä Snellman tuomittiin kesäkuussa 1839 sadan taalarin 48 ruplan sakkoihin esimiesten käskyjen vastustamisesta. Riita oli tärkein syy siihen, että yliopisto menetti Snellmanin opettajakuntansa joukosta. Klassisen saksalaisen filosofian dialektiikalla tietoisuutensa koulineen dosentin rikkeenä oli ollut uskoa varhaisen tottumuksen itsehallintoon, vastapainona hallinnolliselle ohjailulle ja ulkoiselle pakolle, opettavan ihmisen oikein käyttämään vapauttaan.

Snellmanin ajatukset yliopistovapaudesta liittyivät porvariston edistyksellisen nousukauden suurten ihanteiden kehittelyyn. Kun Suomen yliopistoissa kymmenen vuotta sitten alkoi ilmetä uudentyyppistä liikehdintää osana yleisempää kapitalistisen maailman koulutusjärjestelmän kriisiytymistä, ei akateemisen vapauden ajatuksen edistyksellisyyttä tietenkään voinut todeta ympäröivästä todellisuudesta. Siihen saattoivat kiinnittää huomion vain kaikkein terävimmät historialliset analyysit.

Ajatus, jolla porvariston nousun kaudella oli ollut tärkeä yliopistoa yhteiskunnalliseen tehtäväänsä yhdistävä merkitys, muuntui porvariston vakiinnutettua asemansa yliopistoa yhteiskunnasta ja etenkin sen uusien voimien, työväenluokan noususta sopivan etäisyyden päässä pitäväksi, tiedettä yhteiskunnallisesta tehtävästään irroittavaksi. Kapitalismin koulutus- ja tiedejärjestelmän kriisin laajennuttua viimeisten kymmenen vuoden aikana ensi sijassa opiskelijoiden kokemasta kaikenkattavaksi, ei huoli enää voi keskittyä yliopistojen norsunluutornimaisuuteen. Nyt olemme siirtymässä uuteen vaiheeseen, avoimeen barbariaan, jossa porvaristo on valmis luopumaan edistyksellisen kautensa perinnöstä myös tiedettä ja yliopistoja koskevan ajattelun osalta ja hyökkäämään sitä vastaan.

Vapauden ajatuksen tärkeyttä perustelemaan ei tarvita hegeliläistä uskoa maailmanhistoriaan edistyksenä vapauden tietoisuudessa. Totta tässä idealistisessa uskossa on kuitenkin se, että vapauden ajatus ei ole sidoksissa mihinkään yhteen yhteiskuntamuodostumaan vaan siirtyy muuntuneessa muodossa aina kulloinkin edistyksellisimpien historiallisten voimien puolelle, osana näiden hyväkseen käyttämää rikastuvaa ja täsmentyvää humanismin perintöä, sen järkevää ydintä.

\section{Humboldtilaisen yliopistoajatuksen historialli- nen merkitys}

Kun yliopistot suhteellisen kiinteinä rakenteina keskiajalla syntyivät, ne muodostettiin ajan tapojen mukaisesti ylioppilaiden ja oppineiden itsehallinnollisiksi korporaatioiksi, jotka kirkko auktorisoi ja maallinen hallitsija tunnusti. Se, keistä korporaatio koostui, vaihteli jonkin verran. Bolognassa se koostui ylioppilaista, Pariisissa opetusluvan haltijoista. Vaihtelua oli myös siinä, mihin opinaloihin yliopistot keskittyivät: oi- 
keustieteeseen, teologiaan, lääketieteeseen. Kaikenkattavaa yleispätevyyttä vanhimmat yliopistot eivät tavoitelleet. Sellainen universitas syntyi vasta paljon myöhemmin. Yliopistot olivat ammattisuuntautuneen koulutuksen keskuksia, opetuslaitoksia, jotka tuottivat pappeja, lakimiehiä, virkamiehiä ja lääkäreitä.

Uuden ajan alkupuolella yliopistot eivät pääpainollisesti opetustehtäviin keskittyneinä laitoksina kyenneet toimimaan esiin murtautuneen uuden tieteellisen tutkimuksen, erityisesti luonnontieteiden kehtona. Uusi metodi ja siihen liittyvä luonnontieteistä yleistetty maailmankatsomus, joka asetti perinteisen kirkollisen auktoriteetin kyseenalaiseksi, vastasivat esiin tunkeutuvan porvariston tarpeita, joten juuri vallankumousajan Englanti, ensimmäisen porvarillisen vallankumouksen kotipaikka, muodostui luonnontieteisiin nojaavan liikkeen keskukseksi ja maaksi, jossa tieteellisen tutkimuksen yhteisö omine metodeineen, päämäärineen ja peruskatsomuksineen erottui muista yhteiskunnallisista toiminnoista suhteellisen itsenäiseksi toimintojen piiriksi.

Tieteen uuden autonomian kantajia eivät kuitenkaan olleet yliopistot, vaan tutkimus siirtyi pitkälti yliopistojen ulkopuolelle, tieteellisiin seuroihin ja akatemioihin, maineikkaimpina Englannin Royal Society ja Ranskan Académie des sciences.

Tilanteeseen reagoitiin eri puolilla eri tavoin. Ranskassa Napoleon lakkautti vanhat yliopistokorporaatiot kokonaan. Tilalle luotiin keskitetysti valtiojohtoinen järjestelmä, jossa eri korkeakoulujen ja laitosten tehtävät olivat toisistaan poikkeavat ja tarkoin määritellyt sekä opintojen kulku, tutkinnot ja oppilasotot samoin säädellyt. On sanottu, että tämä merkitsi kadettikouluperinteen tuomista yliopistolaitokseen.

Tutkimus säilyi tässä järjestelmässä opetuksesta erotettuna, yksityisluonteisena toimintana, amatöörityönä. Ranskalainen yliopisto ei kyennyt imemään sitä sisäänsä, elimelliseksi osak- seen, millä oli puolestaan seuraamuksensa koko tämän tiedejärjestelmän pitkän tähtäyksen kehitysedellytyksille.

1800-luvun puoliväliä lähestyttäessä ranskalainen tiede menetti kärkiasemansa. Koulutus- ja tiedejärjestelmä ei ollut merkittävästi uudistunut laadullisessa mielessä ja se oli kehittynyt liian jäykäksi. Se ei kokonaisuutena kyennyt vastaamaan uusien tutkimus- ja koulutustehtävien haasteisiin, niitä varten piti aina perustaa uusia laitoksia, mikä oli tehotonta uusiutumista. Se ei kyennyt tarjoamaan järjestettyä tutkijankoulutusta, minkä vuoksi liian paljon jäi riippumaan tutkijoiden yksilöllisistä ominaisuuksista ja mahdollisuuksista. Vieroksuessaan pikaista ja laajamittaista uusien haasteiden omaksumista se ruokki järjestelmällisen tutkimuksen vastakohtana individualismia ja heikensi näin kykyä sekä kansallisen että kansainvälisen tason tieteelliseen kanssakäymiseen.

Ratkaisevaa edistystä merkitsivät Berliinin yliopiston perustamisessa keskeisinä olleet Wilhelm v o n $\mathrm{H} \mathrm{u} \mathrm{m} \mathrm{b}$ o $1 \mathrm{~d} \mathrm{t} \mathrm{i} \mathrm{n} \mathrm{yliopistolaitosta}$ koskevat ajatukset, jotka alkoivat saada kasvavassa määrin jalansijaa. Klassisen saksalaisen filosofian hengessä vapauden ajatus nostettiin yliopistolaitoksen kannalta uudella tavalla keskeiseksi. Tunnukseksi tuli B i $1 \mathrm{du} \mathrm{n}$ g $\mathrm{durch}$ W is s e $\mathrm{s} \mathrm{ch}$ a $\mathrm{ft}$, kasvatus tieteellisen kyselyn vapaassa ja kriittisessä hengessä, se persoonallisuuden kaikinpuolinen kehitys, jota nimitettiin 'sivistykseksi'.

Kant kirjoitti, että tiedettä voidaan "ajatella vain järjen, ei hallituksen lainsäädännön alaiseksi". Fichte ja Schleiermacher muotoilivat ajatusta yleisestä inhimillisestä sivistyksestä, joka voi kasvaa vain sisältäkäsin ja vapaudessa. Tällainen sisältä kasvava tiede oli heidän mielestään luonnetta muodostavaa. Juuri luonteesta ja toiminnasta oli taas kysymys valtiossa, jonka tehtäviin sivistyneistön tuli asettua. Idealistien vapaus ei suinkaan ollut mitään valtiolle vastakohtaista, vaan väline valtiollisessa kasvatuksessa. "Kun- 
han ensin ajatusten valtakunta on kumouksellistettu, ei todellisuus kykene pitämään puoliaan”, kirjoitti Hegel kerran. Sama usko yhdisti saksalaisen yliopiston uudistajia.

Tieteellisen elämän autonomialla ei ollut pelkkä itsetarkoituksen arvo, vaan se nähtiin tarpeelliseksi yliopistojen ammattikasvatustehtävän toteuttamisen kannalta. Omistautumisen teoreettiselle ajattelulle uskottiin antavan toiminnalle painokkuutta ja siveellistä merkitystä, kuten Schelling luennoissaan akateemisista opinnoista oli esittänyt. Sen vuoksi tiedekuntien arvohierarkiassa ylimmäksi kohotettiin humanistiset ja luonnontieteelliset oppiaineet sisältävä filosofinen tiedekunta. Teologista tiedekuntaa ei enää hyväksytty tähän asemaan, mutta toisaalta tätä asema ei myöskään haluttu antaa esimerkiksi Ranskassa ihailluille tiukan käytäntösuuntautuneesti ammattikoulutukseen keskittyneille tiedekunnille. Teoria katsottiin persoonallisuutta ja maailmankatsomuksellista pohjaa kehittävän voimansa takia käytäntösuuntautuneisuutta käytännöllisemmäksi.

Yliopiston itsehallinto suhteessa valtioon ei ollut tämän yliopistokäsityksen lähtökohtia, joskin hyvin väljässä mielessä sen seuraamuksia. Tieteen autonomian ajatuksella oli alkuperäyhteytensä omantunnonvapauden vaatimukseen, joka liittyi polemiikkiin valtiokirkollista uskontoa vastaan. Mitään ristiriitaa ei sen vuoksi nähty siinä, että uudistuneen yliopiston erikoisasema itsehallinnollisena korporaationa jopa heikentyi samanaikaisesti, kun yliopiston sisällä pyrittiin toteuttamaan a k a d e $\mathrm{mi} \mathrm{s} \mathrm{c} \mathrm{h} \mathrm{e}$ $\mathrm{F} \mathrm{r}$ e i h e i t, akateeminen vapaus.

Viimeksi mainittu käsitettiin koostuvaksi kahdesta osasta, jotka olivat $\mathrm{L}$ e $\mathrm{n}$ f r e ihei t ja L e h r f e i he it, opintojen vapaus sekä toisaalta tutkimuksen ja opetuksen vapaus. Vaikka porvarilliset vapaudet muualla yhteiskunnassa olivat rajoitetut ja vaikka humboldtilainen yliopistoajatus kohtasi monia vaikeuksia, Preussin perustuslakiin kirjattiin 1800-luvun puolivälissä vaatimus, että "tieteen ja sen opetuksen on oltava vapaata". Vuosisadan loppupuolella tämä vapaus oli saksalaisten professorien erityisenä ylpeyden aiheena, joskin tässä vaiheessa vapauden ulottaminen kaikkiin yliopistoyhteisön jäseniin jo hämärtyi, koska eri yliopistosäädyillä oli hyvin erilainen asema ja asemaan liittyvä valta.

Humboldtilaiseen yliopistoajatukseen sisältyi se vaatimus, että tutkijoiden tuli saattaa opiskelijat osallisiksi itse tieteellisen tutkimuksen prosessista. Sivistyksen, hengen sisältäpäin kohoavan kehityksen kirvoittamisen myös koulutettavissa sekä kulttuurin perinnön perinpohjaisen omaksumisen katsottiin edellyttävän tätä. Yliopiston opettajat pystyivät tähän ilmeisestikin vain silloin, jos he olivat eteviä tutkijoita.

Tältä pohjalta muotoiltiin tutkimuksen ja opetuksen ykseyden vaatimus, jonka mukaan yliopistonopettajan tuli olla etevä tutkija ja hänen opetustoimintansa tuli liittyä hänen tutkimukselliseen suuntautumiseensa. Tällaisten tunnustähtien johtamina saksalaiset yliopistot omaksuivat vähä vähältä sisäänsä sen tieteen, joka uuden ajan alkupuolella oli jäänyt yliopistojen ulkopuolelle. Yliopistoista muodostui Saksassa toisin kuin esimerkiksi byrokratiansa kouriin jäykistyneessä Ranskassa luovan tieteellisen tutkimuksen tyyssijoja, eikä niiden koulutustehtävää nähty ritiriitaiseksi tähän tehtävänasetteluun sisällytettyjen vapauksien kanssa vaan päin vastoin näitä vapauksia edellyttäviksi.

Erityisen tärkeiksi muodostuivat ne tieteellisten ansioiden arvioimisen menettelyt, joilla akateemisia opettajia pyrittiin valikoimaan. Jos professoriyhteisön itsehallinto yhdessä yliopistossa muodostui liiaksi uusia näkemyksiä vieroksuvaksi itseään täydentäessään, sen virheet tässä mielessä saattoivat korjautua muissa yliopistoissa ainakin niin kauan kuin tiedejärjestelmä kokonaisuudessaan oli voimakkaassa laajentumisen tilassa, kuten se 1800-luvun Saksassa oli, ja kun valtakunnallinen ja kansainvälinen tieteelli- 
nen mielipide pääsivät vaikuttạmaan asiaan paikkakuntakohtaiset pikkumaisuudet ohittaen. Onkin todettava, että saksalainen yliopistolaitos kohosi 1800-luvun jälkipuoliskolla yleismaailmallisissa mitoissa esikuvalliseen ja tieteen kehitystä johtavaan asemaan.

Heikentyneenä ja muuntuneenakin Wilhelm von Humboldtin ja hänen aikalaistensa sivistysidealismin kaiku palveli tieteellisen tutkimuksen muodostumista ammattiuraksi, minkä tulokset myös näkyivät. Luovan tutkijan yliopistonopettajana edellytettiin käyttävän aikaansa uuden tutkijapolven innostamiseen ja kasvattamiseen.

Akateemisen vapauden ajatus tarjosi mallia yliopiston aatteellisen pohjan uusimiselle myös monissa muissa maissa, esimerkiksi Yhdysvalloissa, josta käytiin Saksassa oppia noutamassa. Eroja oli tietysti lukuisia. Professorien itsehallinto oli vierasta amerikkalaisen yliopiston liikkeenjohdolliselle hallintotavalle, humboldtilainen ajatus opiskelun vapaudesta oli matkalla kadonnut, empiristiset ja pragmatistiset vaatimukset tekivät tyhjäksi näkemyksen yliopistotyön maailmankatsomuksellista pohjaa kehittävästä merkityksestä. Kuitenkin se raportti akateemisesta vapaudesta, jonka American Association of University Professors vuonna 1915 julkaisi, sisälsi nimenomaan tutkimuksen ja opetuksen vapaudesta monia klassisina pidettäviä muotoiluja.

Tässä raportissa lähdettiin siitä, että nykyaikainen yliopisto on kasvavassa määrin "tulossa... tieteellisen tutkimuksen kodiksi" ja että edistyksen ehtona kaikilla tieteenaloilla on "täydellinen ja rajoittamaton vapaus harjoittaa tutkimıusta ja julkaista sen tulokset". Myös tämän vapauden merkitystä opetustoiminnalle korostettiin: "'Merkitystä ei ole ainoastaan opetuksen vaan myös opettajan laadulla, sillä jos opiskelijalla on aihetta epäillä, ettei opettaja ole avoin, opetuksen kasvatuksellinen voima kärsii tästä verrattomasti. Opettajan mieltä eivät saa sitoa mitkään henkiset rajoitukset. Hänen on annettava opiskelijalle parasta, mitä hä- nellä on ja mitä hän on." Raportti otti selvästi kantaa amerikkalaisten yliopistojen rahoittajien ja hallintoelinten pyrkimyksiin sitoa yliopistonopettajat monin tavoin tarkoitusperiinsä ja tuomitsi nämä mielivaltaisiksi ja hylättäviksi. Ammattikuntansa lisäksi yliopiston professorit olivat raportin mukaan vastuussa "julkiselle elämälle" ja "jälkimaailmalle", mutta eivät näiden nykyisille edustajille, vielä vähemmän julkiselle mielipiteelle. Pikemminkin yliopiston tulisi olla "älyllinen kokeiluasema, jossa uudet ajatukset voivat syntyä ja jossa niiden hedelmät, vaikka olisivatkin vastenmielisiä yhteiskunnalle kokonaisuudessaan, voivat kypsyä voidakseen lopulta ehkä muodostua osaksi kansakunnan tai maailman hyväksyttyä intellektuaalista ravintoa".

Raportti ei jätä epäselväksi sitä, miltä taholta tutkimuksen ja opetuksen vapautta uhkaa vaara. Siinä viitataan siihen, että amerikkalaisten yliopistojen hallintoportaan edut kietoutuvat "suuriin yksityisyrityksiin". Edelleen yliopistojen "hyväntekijät, sekä useimmat vanhemmat, jotka lähettävät lapsensa yksityisesti rahoitettuihin laitoksiin, kuuluvat itse varakkaampiin ja sen vuoksi tavallisesti konservatiivisempiin luokkiin..." Tämä on raportin mukaan lukemattomien akateemista vapautta koskevien ristiriitojen lähteenä.

Vaatimus akateemisesta vapaudesta, jonka porvaristo nousunsa kaudella itse muotoili kriittisenä, kumouksellisena tunnuksena, on tässä siirtymäisillään sen käsistä yhteiskuntakehityksen uusille voimille. Syvempiä erittelyjä raportti ei kuitenkaan sisältänyt. Ei voi sanoa, että se olisi antanut tutkimuksen ja opetuksen autonomialle uutta sisältöä tai osoittanut sille uusia kantajia. Sen yhteiskunnallinen ponsi jäi voimattomaksi julistukseksi. Yhtenä periaatteen klassisena kirjaanvientinä sitä kuitenkin on pidettävä.

Amerikkalaisessa raportissa ilmaistu vapauden tunnus muodosti verrattain jyrkän vastakohdan sille, millaiseksi akateeminen vapaus Saksassa oli tosiasiassa muodostunut, olkoonkin, et- 
tä raporttia oli osittain motivoinut Saksassa saatu oppi. Vuoden 1848 epäonnistuneen kumouksen jälkeen Preussin valtio oli jotain toista kuin se uudistuksia toteuttava, sivistyksen varaan rakentava Preussi, joka kajasti Wilhelm von Humboldtin, Hegelin ja muiden tulevaisuuskuvassa ja odotuksissa. Vapaus, jonka oli ollut määrä toimia esikouluna tietyntyyppiseen valtioon, tuli nyt kytkeytymään toiseen yhteyteen.

Samanaikaisesti ulkonaisen merkityksensiirtymän kanssa myös saksalaisen yliopiston sisäisen rakenteen rajat alkoivat tulla ilmeisiksi. Maailmankatsomuksellinen pohja, klassinen saksalainen filosofia, oli hajonnut. Alunperin pohja ei ollut vaikuttanut hedelmällisesti juuri muihin kuin humanioraan, mutta pian sen epäsuora vaikutus alkoi koitua luonnontieteellisen perustutkimuksen hyväksi. Sen perintöä olivat monipuolisen oppineen kuvan mukaisesti mitoitetut, laaja-alaiset, peruskysymyksiä koskevaan tutkimukseen ja opetukseen suunnatut professorin virat. Filosofisen pohjan lakastuttua näiden virkojen yleisyys alettiin puolestaan käsittää yhä ehdottomammin, käytäntöön kytkeytyvät ongelmat luotaan sulkevaksi. Tieteenalajako vakiintui ja alkoi hyljeksiä monitieteisiä, välialueille sijoittuvia kysymyksenasettelun tapoja. Tieteiden kehitystä edistänyt yleisyyden vaatimus muodostui sen jarruksi.

Määrällisen kasvun pysähtyessä saksalainen yliopistolaitos kävi kyvyttömäksi laadulliseen muuntumiseen. Aatteellisen pohjan rapautuessa niin sanottujen ordinariusten, varsinaisten professorien kollegio käsitti itsensä yhä enemmän yliopistovapauden ainoiksi kantajiksi. Yliopiston sisällä ordinarius esiintyi feodaaliherrana. Hänen ei tarvinnut ottaa huomioon muita opettajatutkijoiden kategorioita, opiskelijoista puhumattakaan. Vapaudesta tuli ordinariusten vapautta, ei enää koko yliopistoyhteisölle kuuluvaa.

Humboldtilainen yliopistoajatus oli sisältänyt sen vaatimuksen, että professorien toimia tulee voida kontrolloida. Kullakin alalla tuli olla dosentteja, P r i va t d o z e n t e n, jotka veisivät erikoistunutta tutkimusta eteenpäin ja tieteellisellä auktoriteetillaan muodostaisivat ordinariusten toimia tasapainottavan voiman. Opiskelijoiden puolestaan odotettiin kontrolloivan opettajiaan siten, että hyvä luennoitsija sai paljon kuulijoita ja jälkikasvua, huono jäi ilman.Kumpikaan kontrolleista ei osoittautunut toimivaksi. Kaikki todellinen valta keskittyi ordinariuksille.

Saksalaiset yliopistot muodostuivat tiukan säätyjakoisiksi. Asemansa parantamiseksi ekstraordinariukset ja dosentit perustivat tosin erilaisia valtakunnallisia liittoja, tuloksetta. Vallan jako säätypohjalta ehkäisi tieteellistä kehitystä. Dosentit tai ekstraordinariukset saattoivat olla alallaan huippua, vaikka heille ei auennut tietä ordinariuksiksi. Tällöin heidän mahdollisuutensa vaikuttaa laitoksiin, tutkimuslaboratorioihin ja vastaavaan jäi olemattomaksi, sillä laitosten käsitettiin olevan olemassa ordinariusprofessoria varten.

Vapaus oli alunalkaen valtioon päin kallistunut, mutta kallistuma yhä lisääntyi imperialismin kauden Saksassa ja sai näissä oloissa uuden poliittisen sisällön. Dosentin esiintyminen sosialidemokraattien tilaisuudessa saattoi riittää aiheeksi hänen opetuslupansa poistamiseen, sitä vastoin imperialismia, aggressiivista sotapolitiikkaa ja rasismia ihannoivien oppien kehittely ei antanut muuntuneen "akateemisen vapauden" kannalta aihetta huomautuksiin. Ensimmäisessä maailmansodassa saksalainen professorikunta ansaitsi varsinaisesti saappaankorkonsa asettumalla koko arvovallallaan tukemaan sotapolitiikkaa. Samalta taholta lähti myöhemmin kärkevä ja tuloksekas kritiikki Weimarin tasavaltaa kohtaan.

Puhe linnoittautumisesta norsunluutorniin antaa noista ajoista väärän kuvan: tornin norsunluista osaa tuettiin vahvasti pääkallojen vallituksilla ja sääriluiden tukipuilla. Samalla kaikenlainen näennäistiede, kunhan se pukeutui 
riittävään auktoriteettiin, voitti aidon tieteellisyyden pyrkimyksen. Yliopistojen tiukka säätyjako ei ollut vailla syyllisyyttä tapahtuneeseen. Kun tieteellisen argumentin painon riittivät murtamaan valta-asemat ja professoriprivilegiot, olivat tuhon edellytykset lasketut.

Saksalaiset yliopistot menettivät tieteiden kehitystä johtavan asemansa jo ennen suoranaista fasismin nousua ja paljolti edellä luetelluista syistä. Vertailun vuoksi voi todeta, että esimerkiksi amerikkalaisten yliopistojen ajatus osastoista, $\mathrm{d}$ e $\mathrm{p}$ a $\mathrm{r} \mathrm{t} \mathrm{m}$ e $\mathrm{n} \mathrm{t}$ oli ordinariuksen herruuteen nojaavaa laitosta demokraattisempi, vaikka siihen muussa yliopistohallinnossa liittyikin varsin liikkeenjohdollinen hallintatapa. Osasto, jonka piiriin kuului suuri joukko tutkijoita, edusti epälyksittä laajaa ja jatkuvasti kehittyvää tieteenalaa yhtä ainoata, lähes kaikkivoipaiseksi kuviteltua ordinariusta paremmin. Myös moniteiteisille kysymyksenasetteluille, systemaattiselle tutkijankoulutukselle ja muille yliopistojen uusille haasteille se tarjosi demokraattisemman, tutkijoiden suurempaa tasaarvoisuutta toteuttavan luonteensa takia paremman kasvuperustan ja kehittymisedellytykset. Kapitalistisessa maailmassa juuri se kykeni omaksumaan tieteellisen edistyksen haasteita niitä hyljeksiviltä saksalaisilta yliopistoilta, ohittamaan nämä tieteellisessä merkityksessään ja painossaan.

\section{Tieteellisen sivistyksen ajatus Snellmanin ke- hittelemänä}

Turun akatemian perussääntöjen ensimmäisen pykälän mukaan oli luvallista opettaa ainoastaan sellaista, mikä oli sopusoinnussa raamatun ja Augsburgin muuttumattoman tunnustuksen kanssa. Seuraavassa pykälässä akatemia selitettiin itsehallintoa nauttivaksi korporaatioksi. Nämä säännöt, Constitutiones Carolinae, pätivät sen ajan loppuun saakka, jonka yliopisto oli $\mathrm{Tu}$ russa.

Pian Helsinkiin muuton jälkeen, vuoden 1828 lopussa, keisari vahvisti uudet säännöt. Uusien sääntöjen ensimmäinen pykälä kuului: "Keisarillisen Aleksanterin yliopiston tarkoituksena on edistää tieteiden ja vapaiden taiteiden vaurastumista Suomessa sekä sen ohessa kasvattaa sen nuorisoa kykeneväksi palvelemaan keisaria ja isänmaata." Vapaat taiteet, a r t e s $1 \mathrm{i}$ b er a 1 e s, tarkoitti tässä lähinnä filosofisen tiedekunnan humanistisia ja luonnontieteellisiä oppiaineita vastakohtana muiden tiedekuntien ammattisuuntautuneille oppiaineille.

Uskontoa uusissa säännöissä suojeli ainoastaan yksi viittaus pykälässä 127: 'Kaikilla opettajilla on siten oikeus järjestää ja suorittaa luentonsa sillä tavalla kuin he katsovat parhaaksi rehellisen opin ja todellisen valistuksen ilmoittamiseksi ja levittämiseksi kuulijoiden keskuuteen; kuitenkin ottaen huomioon, etteivät he esitä mitään, mikä on vastoin uskonoppia, isänmaan lakeja ja siveellisyyttä.",

Vuonna 1923 annetussa laissa Helsingin yliopistosta todetaan ensimmäisessä pykälässä ainoastaan: "Yliopiston tehtävänä on edistää vapaata tutkimusta ja tieteellistä sivistystä Suomessa sekä kehittää sen nuorisoa kykeneväksi palvelemaan isänmaata”. Opetuksen tuli palvella tässä mainittujen tarkoitusten edistämistä, mutta muutoin yliopiston opettajilla lain mukaan oli opetusvapaus ilman niitä uskon tai hallitusmuodon suojaamiseen tähtääviä rajoituksia, jotka aiemmin olivat olleet voimassa. Samantapaisia muotoiluja sisältyy myös myöhemmin perustettuja yliopistoja koskeviin lakeihin, esimerkiksi Oulun yliopistoa koskevaan, jossa niin ikään esitetään tehtäväksi muun muassa edistää "vapaata tutkimusta ja tieteellistä sivistystä’.

Mainittu kaksiosainen ilmaisu "vapaasta tutkimuksesta ja tieteellisestä sivityksestä" on se ni- 
menomainen side, joka yhdistää - joskin historiallisesti katsoen hatarasti - Suomen yliopistolainsäädäntöä humboldtilaiseen yliopistoajatukseen. Kuten totesin, Snellman kirjoitti, että "yliopiston, sivistyslaitoksena, tulee ohjata nuorisoa lapsellisesta auktoriteettiuskosta itsenäiseen vakaumukseen". Humboldtilais-snellmanilaisen käsityksen mukaan yliopisto edelyttää sivistyslaitoksena tietyt perusvapaudet.

Vuonna 1840 Snellman julkaisi, riitansa jälkeen Ruotsiin siirryttyään, vihkosen "Om det akademiska studium", jossa hän pitämättä jääneiden luentojensa teemaa kehitellen selosti käsitystään tieteellisestä sivistyksestä. "Käsitämme tässä yliopiston pelkästään sivistyslaitokseksi, koska tämä käsitys... sisältää myös yliopiston tarkoituksen tieteiden vaalijana", Snellman kirjoitti. Snellmanilla sen enempää kuin klassisessa saksalaisessa filosofiassa tieteen vapauden vaatimus ei ollut pelkkä itsetarkoitus vaan johdettavissa yliopiston tehtävästä sivistyslaitoksena.

Akateeminen vapaus merkitsi Snellmanille "itsetajunnan oikeuden" tunnustamista, oikeutta "ratkaista i t s e, arvioida i t s e sekä tietämisessä että toiminnassa”. Tämän oikeuden puuttumisesta Snellman arvosteli aikansa yliopistoa, joka muistutti hänestä koulua läksynlukuineen, ennalta määrättyine oppiaineineen, oppikursseineen, oppikirjoineen. Sen vastakohdaksi hän luonnosteli käsitystään yliopistosta sellaisena kuin sen tulisi olla, todellisesta yliopistosta: "Yliopistoon ei kuulu mikään tällainen... Kaikki on täällä vapaata, riippuu ylioppilaan vapaasta valinnasta, työstä tai laiminlyönnistä, työstä omin päin tai opettajan opastuksella, oppiaineet, opintojen järjestys, järjestelmät ja kirjailijat, sanalla sanoen: akateemisille opinnoille ei ole muuta sidettä kuin ylioppilaan oma mieltymys ja arviointi.",

Opintojen vapauden Snellman katsoi kasvattavan luonnetta sekä johdattavan koulusta yliopistoon siirryttäessä jo heränneen "itsetajun- nan" omin ponnistuksin taisteltuun sovintoon perinteen kanssa. Läksynluku oli "itsetajunnalle" vieras työtapa. Sen olemukseen kuului päinvastoin kenenkään estämättä reflektoida esitettyjen väittämien totuutta, kysyä, epäillä, esittää kritiikkiä, kieltää valmiina tarjoiltu, jäsentää ja koota tietoainesta omatoimisesti sekä edetä tutkivaan, luovaan ajatustapaan. Snellman ei itsetajunnasta puhuessaan saarnannut anarkismia, sillä hän määritteli tietämisen oivallukseksi perinteeseen sisältyvästä järjellisestä. Sellaisen oivalluksen syvyyttä ja kasvatuksellista merkitystä vain lisäsi tavattomasti se, että opiskelija päätyi siihen tunnustetun itsetajunnan oikeutensa, omakohtaisten ponnistelujensa ja hankkimansa luovan tieteellisen ajattelun kyvyn pohjalta.

Viimeksi mainitun hankkimisen ehtona oli puolestaan se, että yliopistollinen opettaja ei ollut koulunopettajan kaltainen, arvostelun ulkopuolella oleva auktoriteetti. Snellmanin mukaan "jokainen auktoriteetin ilmentymä yliopistonopettajassa saa aikaan sen, että oppilas kokee hänen oppinsa vastenmieliseksi ja alistaa sen tarkasteluun pelkästä virheiden ja kritiikin aiheiden etsimisen halusta". Yliopistonopettajan tulee luennoissaan "ennen kaikkea tehdä selväksi, että hänen tietämisensä on o m a a tutkimusta, eikä pelkästään esittää tuloksia, vaan siinä määrin kuin mahdollista johdattaa kuulija sille tielle, jota itse on vaeltanut". Näin kuulija johdatetaan oivallukseen siitä, mitä todellinen tutkiva opinto, akateeminen "studium", on: "Sillä opettajan osoittaessa tutkimuksen ja arvioinnin oikeutta oppilaan on helppo tehdä se johtopäätös, että myös hänelle kuuluu sama oikeus."

Tällainen opetus on Snellmanin mielestä yliopistossa sivistystään etsivän nuorison itsetajunnan oikeuden "ensimmäinen ja tärkein tunnustaminen". "Sellainen yliopistonopettaja puolestaan", Snellman toteaa, "joka ei kykene välittämään ylioppilaalle sellaista opetusta eikä kykene herättämään ja ylläpitämään hänessä kiinnos- 
tusta tietämiseen johdattamalla hänet vakavaan tutkimukseen, on tehtäväänsä kelvoton. On tyhjää puhetta sanoa yliopistonopettajasta: 'Hän ei ole mikään tiedemies, mutta kunnon opettaja'. Sillä jollei hän ole ensin mainittua, eikä hän ole jälkimmäistäkään. Hän voi siinä tapauksessa olla kunnon opettaja kouluun, mutta sitä hän ei ole yliopistolla."

Tämä tutkimuksen ja opetuksen ykseys puolestaan edellyttää sitä, että yliopistonopettajan on "mieltymyksensä mukaan valittava tieteestään luentojensa aiheet". Yliopistojen tehtävästä kaikille jäsenilleen itsetajunnan oikeuden tunnustavana sivistyslaitoksena Snellman johtaa vaatimuksen opintojen vapaudesta. Tieteelliset opinnot edellyttävät tällaisen vapauden, mutta ne edellyttävät toiselta puolen myös opetuksen tieteellisyyttä ja vapautta.

Voi sanoa, että Snellmanilla esiintyy pelkän tutkimuksen ja opetuksen ykseyden periaatteen asemasta alkuperäisempi klassisen saksalaisen filosofian inspiroima kolmiportainen tutkimuksen, opetuksen ja opiskelun ykseyden vaatimus, ajatus yliopistosta laitoksena, jonka olemusta määrittelee kaikkien näiden toimintojen vapaus.

Snellmanin näkemys näin toteutettavasta itsetajunnan oikeuden tunnustamisesta suhteessa tieteelliseen sivistykseen sisältää verrattomasti enemmän kuin koulutus- ja tiedeyhteisön autonomian kaventaminen pelkäksi professorien oikeudeksi yliopistoyhteisön hallintoon. On kuvaavaa, että viimeksi mainitun kysymyksen Snellman lähes sivuuttaa akateemisen vapauden käsittelyssään. Se tulee esiin vasta aivan tarkastelun lopussa, muutamassa poleemisessa käänteessä, joilla Snellman tekee selväksi, että akateemisella vapaudella hän ei tarkoita yliopiston oikeutta irtautua yhteiskunnallisesta käytännöstä.

Yliopiston tieteellisessä hengessä tulee Snellmanin mukaan ilmetä myös muiden vaikutusten kuin luonnosteltujen yliopiston sisäisten. "Kun mainitsen kaksi seikkaa, jotka ovat tosi tieteelliselle elämälle välttämättömiä - nimittäin: yliopiston tehokkaan osallistumisen ajankohdan tieteellisiin kiistakysymyksiin sekä ajankohtaisiin isänmaalle tärkeisiin kysymyksiin - olen maininnut vain ulkoiset ehdot, joista määrääminen on yliopiston omassa vallassa.Ilman sellaista toimintaa ei yliopisto voi odottaa mitään tunnustusta, ei sen enempää tieteen maailmassa kuin omilta kansalaisilta."

Keskiaikaisen yliopiston ammattikuntaisuutta, korporatiivista luonnetta vastaan Snellman kohottaa porvarillisen yhteiskunnan vaatimuksen tieteen yleispätevyydestä: "...tieteellinen intressi on jo lakannut kuulumasta killalle ja jokainen yhteiskunnan hyvää koskeva kysymys hakee siitä kernaasti ratkaisuaan. Tiedemiehelle kuuluu sen vuoksi käsittää oma aikansa ja syventyä siihen siinä kohden, missä tietämisen tarvetta on olemassa. Sellaisella ulospäin vaikuttavalla toiminnalla yliopisto saa sisäistä voimaa, ja ylioppilas saa tieteen alalla jo tunnustettuihin opettajiinsa luottamuksen, joka enemmän kuin mikään muu synnyttää hänessä rakkautta tieteisiin.",

Tieteellisen sivistyksen vaatimuksen ajankohtaisuus

Maamme yliopistolaitoksen sukulaisuus saksalaiseen hierarkkiseen, autoritaariseen, professorivaltaiseen järjestelmään myönnettäneen tosiasiaksi. Täällä kehitys tosin on ollut monessa suhteessa tasaisempaa, ilman voimakkaita murroksia. Helsingin yliopiston itsehallinto voi lähes ylpeillä keskiaikaisilla juurilla. Vaikka Snellmanin ajatukset toisin kuin saksalaiset esikuvansa eivät sellaisenaan muodostaneet pohjaa yliopistoreformille, Snellmanin perintö ainakin epäsuoraan vaikutti pitkään Suomen tieteelliseen elämään. Autonomian ajalla yliopiston autonomia oli 
vahva, laaja sekä ajanläheisen tieteellisen ja aatteellisen kehittelyn mahdollistanut. Sen demokraattisen sisällön ja isänmaallisen merkityksen rappeutuminen osui paradoksaalisesti vasta myöhempään aikaan.

Jäljelle jäivät ne tyhjät tynnyrit, jotka syvää rintaääntä kumisten osallistuivat kuluvan vuosikymmenen alussa demokratisointipyrkimysten murskaamiseen. Hallintouudistus kuitenkin elää - väliaikaisten hallintoasetusten irvikuvina, hallintovirastojen byrokraattien sormien syyhynä ja vallan maisteluna, eri puolilla valmistuvina muistoina modifioiduista kiintiöhallinnoista ja sopivasti "ulkopuolisilla" täydennetyistä yliopiston korporaatioiden neuvostoista, pyrkimyksistä tutkinnonuudistuksen epädemokraattisten ja autonomiaa loukkaavien suunnitteluprosessien vakinaistamiseen $\mathrm{jne}$.

Ainoa, mikä näistä viimeaikaisista keskusteluista puuttuu, tuntuu olevan ajatus, näkemys siitä, millainen paikka yliopiston tulisi olla. Yliopistolaitoksen historian tarkastelu tarjoaa kuitenkin opetuksia. Yliopistolaitoksen hallintoa tulee arvioida ensisijaisesti sen kannalta, miten hallintojärjestelmä palvelee tieteellisen tutkimuksen edistymistä ja suo sille mahdollisuuksia. Yliopisto on aina rappeutunut ja tullut lopulta kyvyttömäksi myös koulutuksellista tehtäväänsä suorittamaan, mikäli sen suojissa versova tieteellinen elämä on suorasukaisesti alistettu hallinnollisella kajoamisella, tieteellisyyttä vieroksuvilla ammattikoulutustehtävillä tai vastaavalla. Tieteellisen elämän joustavuus ja vapaus, jotka ovat uusien ajatusten luomisen ja omaksumisen edellytyksinä, ovat tästä vaurioituneet. Tuloksena on ollut koko järjestelmän jäykistyminen ja jääminen ajastaan jälkeen. Vastaavasti autonomia-ajatukset ovat merkittävästi edistäneet tieteiden ja koulutuksen kehittämistä, kun niillä on ollut kriittinen, ei yhteiskunnasta eristämistä palveleva sisältö.
Tältä kannalta on aiheellista kysyä, missä määrin tai missä mielessä humboldtilaiseen yliopistoajatukseen voidaan edelleen katsoa sisältyvän järkevä, nykyaikaiselta pohjalta uudistettava ydin. Kun ajattelemme tieteellis-teknisen kumouksen koulutukselle asettamia vaatimuksia, tätä ydintä on varmasti se tieteellisyyden ensisijaisuus koulutuksellisen tehtävänasettelun osana, joka on ilmaistu tieteellisen sivistyksen ajatuksessa ja jolla alunperin oli syvästi progressiivinen, sekä tieteiden että koulutuksen kehitystä edistänyt merkitys. Tutkimuksen, opetuksen ja opiskelun ykseyden ajatus rakensi yliopiston koulutukselliset tehtävät nimenomaan tieteellisyyden varaan, siitä elämisen nesteestä ammennettaviksi.

Tieteellisen sivistyksen ajatuksessa on samalla ilmaistu yliopistoyhteisön yhtenäisyys. Yliopistossa on erilaisia pätevyyksiä, erilaista suuntaumista ja erilaisia perinteitä, mutta yliopiston jakautuminen virka- ja valta-asemien mukaisesti erilaisiin yliopistosäätyihin ilmaisee pelkästään historiallisen tosiseikan eikä mitään järjellistä välttämättömyyttä. Saksalais-suomalaisen yliopiston perinteinen tiukka säätyjako on päin vastoin ristiriidassa sen perustehtävän kanssa, joka yliopistolla tulisi olla tieteellisen sivistyksen luojana, ylläpitäjänä ja välittäjänä.

Jo Snellman totesi kaikkinaisen itse asian ja sen vaatimusten ylitse menevän auktoriteetin yliopistojen tieteelliselle hengelle haitalliseksi. Saman johtopäätöksen vahvistaa saksalaisen yliopiston historian tarkastelu. Tehtävänä tuleekin olla professoriprivilegioiden purkaminen. Kokemistaan vastaiskuista ja harhateistä huolimatta yliopistohallinnon demokratisoiminen on edelleen ajankohtainen tavoite. Se on tavoite, joka perustuu itse tieteiden ja koulutuksen kehittymisvaatimuksiin.

Yliopistoyhteisön rakenne on Suomessakin viime vuosikymmeninä ratkaisevasti muuttunut. Kun ennen yliopisto koostui ensi sijassa profes- 
soreista ja ylioppilaista, välissä ehkä joitakin dosentteja, näiden rinnalle on paisunut mahtava opettajatutkijoiden joukko tuntiassistenteista apulaisprofessoreihin. Tuleeko tämä koko yhteisö sitten ottaa huomioon siten, että yliopistosäädyt kutkin sisältään valitsevat edustajat laitos- ja yliopistokohtaisiin kiintiöityihin korporaatioiden neuvostoihin? Tätä yhteisöä ei tule ottaa huomioon vaan tämän yhteisön tulee olla se, joka ottaa tai jättää ottamatta huomioon. Muuta sisältöä ei demokratisoitumiselle voi koulutus- ja tiedeyhteisön autonomiaa loukkaamatta antaa.

Mahdollisen avauksen lukkiutuneelle tilanteelle saattaisi muodostaa huomion keskittäminen laitoksen tai aineryhmälaitoksen tasolle, alihallintoon, jonka kehittämistä ei voi tarkastella irrallaan yliopiston keskeisimmistä tieteellisistä ja pedagogisista tehtävistä. Näiden toteuttamisen paras asiantuntemus samoin kuin tähän toteuttamiseen liittyvät välittömät kokemukset ja vuorovaikutusprosessit koskevat nimenomaan tätä koko yliopistoyhteisön elinhermoa, perustasoa; alihallintotasoa, jonka ilmapiiristä määräytyy ratkaisevalla tavalla yliopiston mahdollisuus toimia mielekkääksi ja yhteisesti asetettuja tavoitteita toteuttavaksi koottuna työyhteisönä.

Tämä juuri on se taso, jolla tutkimuksen autonomia toteutuu tai jää toteutumatta. Tämä on myös se taso, jolla voi tietyissä rajoissa puhua opintojen autonomiasta - tutkinnonuudistuksen jälkeenkin, jos koko koulutusohjelmakohtainen opintoyhteisö saa demokraattisesti valitun edustuksensa kautta osallistua opintojen suunnitteluun. Eikö nykyajan opiskelijalta voi odottaa tällaiseen kypsyyttä - kaiken sen jälkeen mitä Snellman sanoi itsetajunnan oikeudesta?

Demokraattista tutkijayhteisöä voisi perustasolla ajatella siltäkin pohjalta, että jokainen tutkimuksellisen yksikön jäsen voisi osallistua yksikköä koskevaan päätöksentekoon ja suunitteluun.

Historiallinen tarkastelu mielestäni osoittaa, että yliopiston demokratisoiminen on sen tutkimuksellisen tehtävän kannalta ja juuri perustasolla vähintään yhtä tärkeää kuin motivoivan, demokraattisen opintoilmaston luominen omalta kannaltaan. On mahdollista ajatella tutkimusneuvoston ja koulutusneuvoston tehtävät tällä perustasolla johonkin rajaan saakka eriytyviksi, mutta tieteellisen sivistyksen yhtenäisyys edellyttää silti monissa kysymyksissä tiivistä kanssakäymistä.

Tapahtuipa yliopistodemokratian tarkempi määrittely miten tahansa sen tulisi antaa perustasolla tutkimuksen, opetuksen ja opintojen vapaudelle uusi sisältö, jossa Snellmanin vaatimus "i t s e ratkaisemisesta, i t s e arvioimisesta" korvautuisi autonomialla tietynasteisena tieteellisen sivistyksen omaksumiseen, välittämiseen ja luomiseen motivoivana itsehallintona, joka $\mathrm{ke}$ hittää kaikkia osallisiaan tasavertaisuuteen tunnustamalla heidän oikeutensa tasavertaisuuteen. 